\title{
Aeolian morphology preserved by lava cover, the Precambrian Mussartût Member, Eriksfjord Formation, South Greenland
}

\author{
LARS B. CLEMMENSEN
}

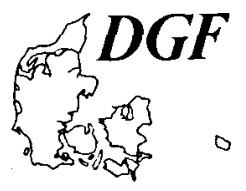

\begin{abstract}
Clemmensen, L. B.: Aeolian morphology preserved by lava cover, the Precambrian Mussartût Member, Eriksfjord Formation, South Greenland. Bull. geol. Soc. Denmark, Vol. 37, pp. 105-116, Copenhagen, October 14th, 1988. https://doi.org/10.37570/bgsd-1988-37-09

Investigations of sedimentary deposits in clastic interval 5 of the Mussartût Member have revealed the occurrence of aeolian sandstones. The aeolian deposits rest on pebbly sandstones and conglomerates of fluvial origin, and the are sharply overlain by a c. $70 \mathrm{~m}$ thick lava flow. The aeolian sandstones comprise up to $10 \mathrm{~m}$ thick and $200 \mathrm{~m}$ wide dome-shaped bodies that are initiated by thin and patchily preserved aeolian sand sheet deposits. The bulk of the aeolian sandstone bodies constitute low-medium-angle, dipping lee-side deposits of dome-shaped dunes. The dome-shaped dunes migrated towards a zone of distal alluvial fans perhaps during the influence of prevailing NE trade winds. Superimposed smaller-scale dunes formed during periodic strong winds from the E. Erosion of the dunes at the base of the lava flow was insignificant and most of the original dome-shape form of the dunes seems to have been preserved. The dome-shaped dunes may represent part of a migrating erg system, but continued dune migration was stopped by extrusion of the lava flow.
\end{abstract}

Lars B. Clemmensen, Institute of General Geology, 'University of Copenhagen, Øster Voldgade 10, 1350 Copenhagen K, Denmark. May 17th, 1988.

The Precambrian Eriksfjord Formation (Poulsen 1964), which crops out on both sides of Tunugdliarfik fjord (Eriksfjord) in South Greenland (fig. 1) is composed of a c. $3400 \mathrm{~m}$ thick succession of continental sediments and lavas. During reconnaissance field work in 1986 on the Ilimaussaq peninsula aeolian sandstones were recognized in several members of the Eriksfjord Formation, and they constitute a significant portion of both the Mussartût Member and the Nunarsarnaq Member.

The sandstones and associated clastic deposits of these members have previously been interpreted as fluvial and shallow lacustrine deposits (Poulsen 1964), and with the exception of one dune structure reported by Stewart (1964) the present account is the first on aeolian deposits in the Eriksfjord Formation.

The aeolian deposits in the Mussartût Member are commonly overlain by lava flows (fig. 2), and the present paper describes the aeolian sandstones of clastic interval 5 (C5) of this member in some detail.

The close association of aeolian sandstones and lava flows has been reported from other forma- tions (e.g. the Early Jurassic Aztec Sandstone, U.S.A.; Porter 1987). The present example, however, seems to be unique by having the original aeolian topography partly preserved beneath the lava flow.

\section{Geological setting and stratigraphy}

The clastic sediments and associated lavas of the Eriksfjord Formation occur in fault-bounded outliers in the Tunugdliarfik area (Poulsen 1964, Emeleus \& Upton 1976). The type section of the formation lies on the Ilimaussaq peninsula and the present paper is based on field work in this region near Sitdlisit on the south coast of the peninsula (fig. 2).

The Eriksfjord Formation is poorly dated. It overlies the Julianehåb Granite (1850-1600 $\mu$ ) and is cut by several intrusive complexes (1310$1291 \mu$ ); the formation contains no unconformities and may be no older than about $1320 \mu$ (Upton \& Emeleus 1987). These dates place the Eriksfjord Formation in the Middle Proterozoic. 


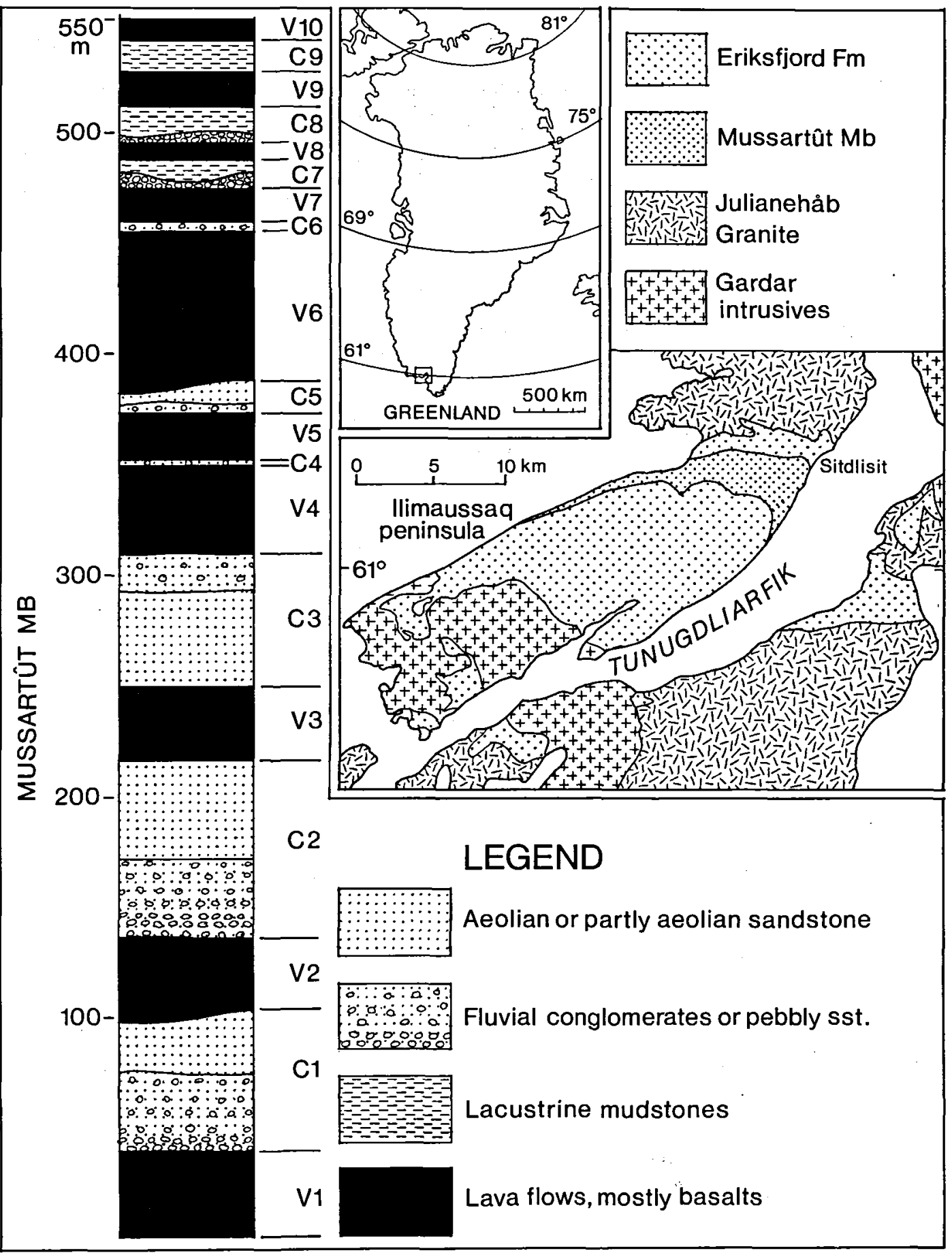

Fig. 1. Simplified sedimentary log of the Precambrian Mussartût Member of the Eriksfjord Formation, South Greenland. Inset: Generalised geological map of the Tunugdliarfik region based on Poulsen (1964). 


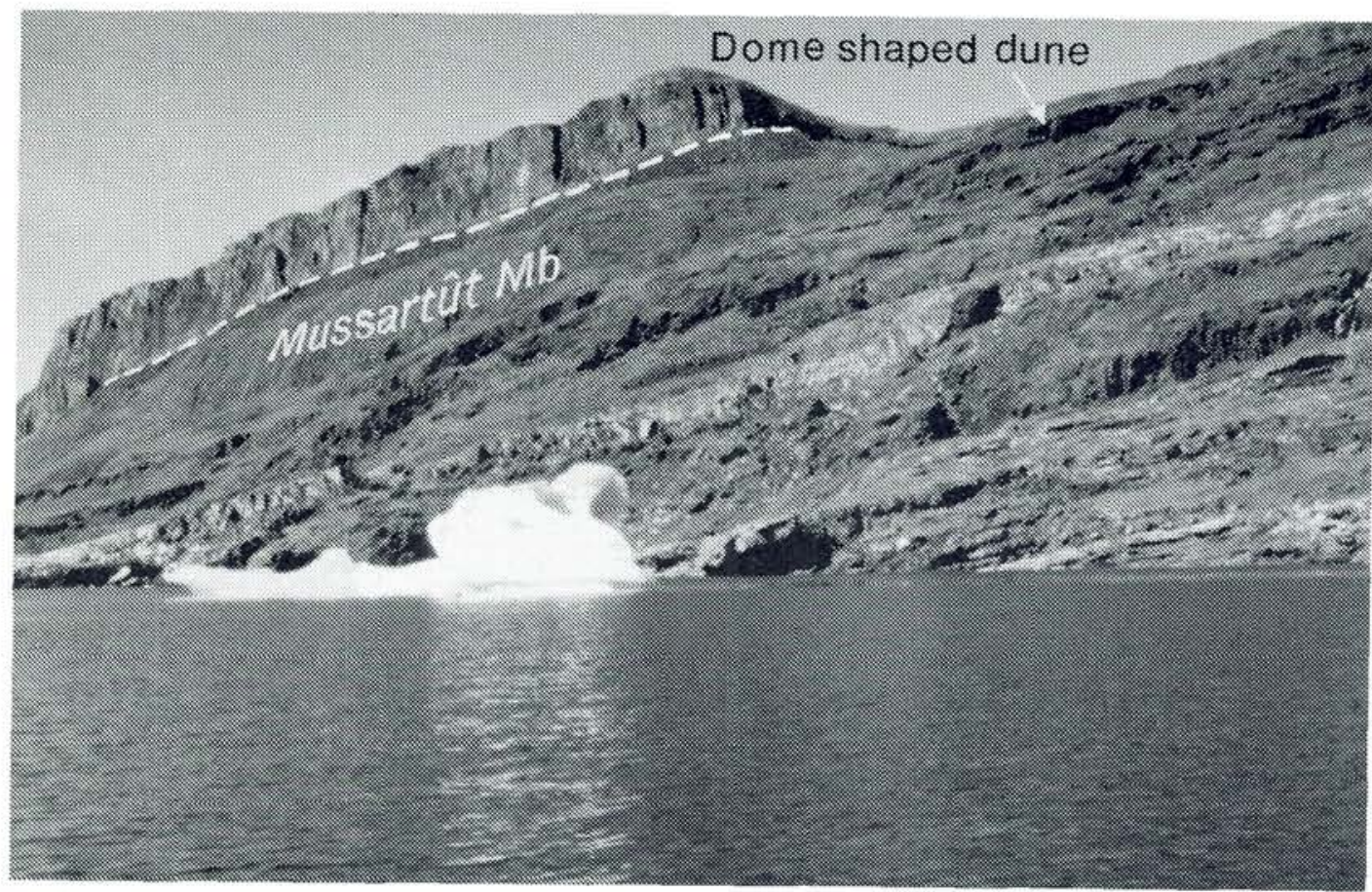

Fig. 2. The uppermost part of the Mussartût Member and the overlying Naujarssuit Member on the south coast of the Ilimaussaq peninsula near Sidlisit. The dome-shaped aeolian sandstone body at locality A in clastic interval 5 is indicated by an arrow.

The formation is composed of six members, and the Mussartût Member is the second member from the base. The member is c. $550 \mathrm{~m}$ thick and composed of almost equal amounts of clastic sediments and volcanic rocks (fig. 1). The member has been informably divided into ten volcanic intervals and nine intervening clastic intervals (Pedersen 1988). Clastic interval 5 (C5), which contains the aeolian sandstones described here, is up to c. $15 \mathrm{~m}$ thick and overlain by a c. $70 \mathrm{~m}$ thick lava flow (V6, fig. 2). The lava flows in the Mussartût Member are basalts or hawaiites (Upton \& Emeleus 1987).

\section{Aeolian facies}

\section{General}

The aeolian deposits in C5 overlie fluvial conglomerates and pebbly sandstones and are locally preserved beneath the thick lava flow in V6 (fig. 2). This lava flow might be compound as judged from its great thickness, but no well-developed hiatus surfaces were observed. The aeolian facies of $\mathrm{C} 5$ were studied between the south coast of the Ilimaussaq peninsula and c. $1.5 \mathrm{~km}$ inland, and within this distance three main outcrops (localities A, B, C) of aeolian sandstones were recognized. The three outcrops lie on a line that run $\mathrm{N}-\mathrm{S}$. Locality $\mathrm{A}$ is situated c. $350 \mathrm{~m}$ from the coast, locality B c. $750 \mathrm{~m}$ from the coast and locality C c. $1100 \mathrm{~m}$ from the coast. Between these outcrops of aeolian sandstones the lava flow appears to rest directly on the fluvial deposits at the base of $\mathrm{C} 5$, but the degree of exposure only rarely allows detailed observations of the contact between the lava flow and the fluvial deposits to be made.

The aeolian deposits are composed of flat-bedded fine- to coarse-grained dune base deposits and low-medium-angle dune lee-side deposits. These aeolian facies are briefly described and interpreted below.

\section{Dune base deposits}

Description. - These deposits are only exposed at localities $\mathrm{A}$ and $\mathrm{C}$. At locality $\mathrm{C}$ they are composed of nearly $1 \mathrm{~m}$ of fine- to coarse-grained 


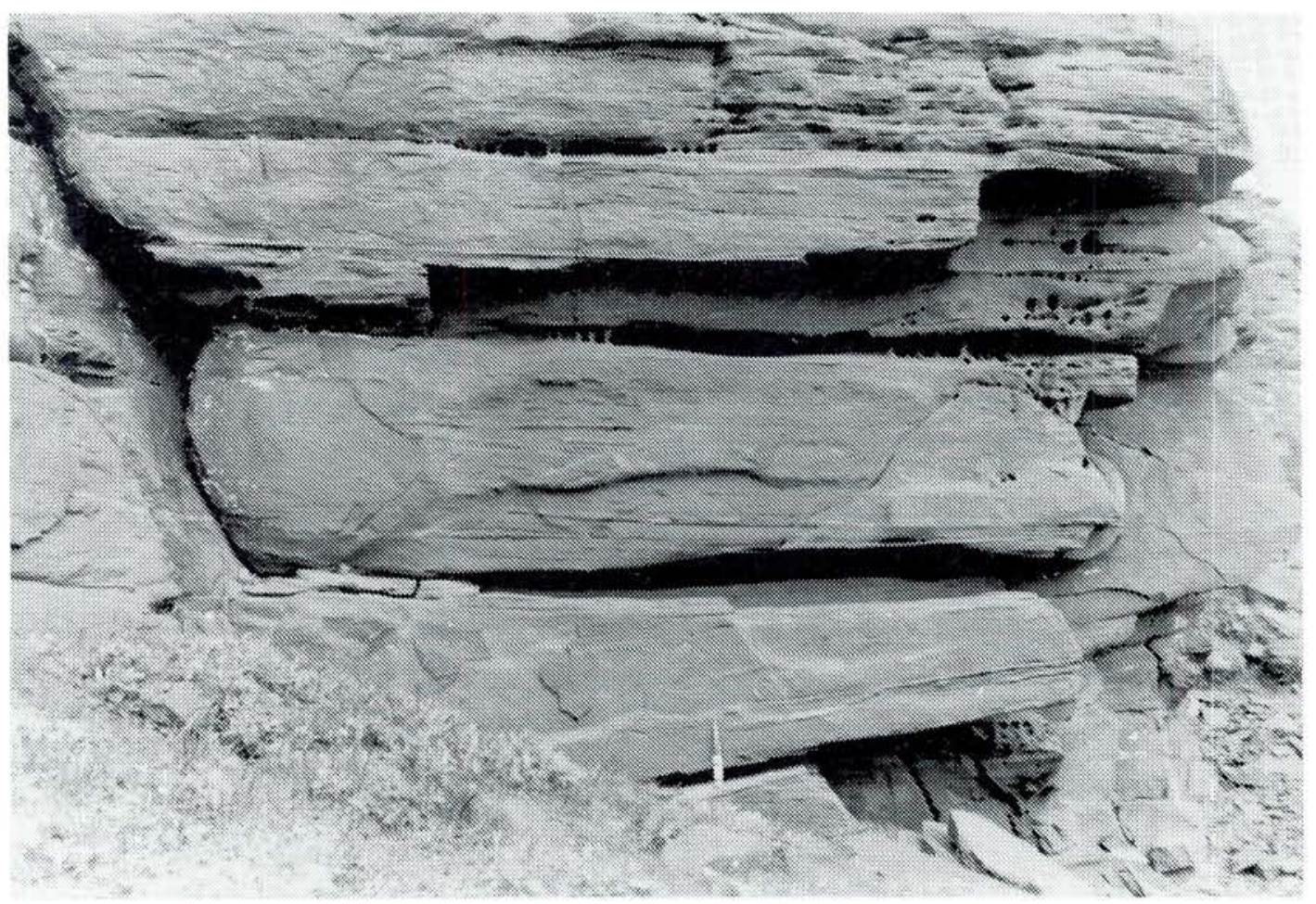

Fig. 3. Dune toesets of dome-shaped dune and underlying small dune structure in sand sheet unit, locality A. The toesets dip very gently towards the NW and contain several third-order bounding surfaces. Knife for scale at the lower contact of the toeset deposits.

sandstones that contain climbing translatent strata (cf. Hunter 1977), well-defined medium sand-granule ripples, very low relief coarse sandgranule ripples ('shields') and a few amoured lag horizons. At locality A the facies is up to $2 \mathrm{~m}$ thick and is initiated by up to $0.8 \mathrm{~m}$ of irregularly laminated fine-grained sandstones (adhesion structures), which are gradually replaced by $\mathrm{c}$. $0.4 \mathrm{~m}$ of medium-coarse-grained sandstones with translatent strata and various medium-coarse sand ripples. On top of this follows a single (c. 0.8 $\mathrm{m}$ thick) high-angle dune set with sandflow strata (cf. Hunter 1977).

At both localities the dune base deposits are abruptly succeeded by low-angle dune foreset deposits.

The dune base deposits are of uneven thickness and may locally be completely lacking beneath the dune foreset deposits; the degree of exposure, however, does not allow a detailed mapping of this facies.

Interpretation. - The sedimentary features of the flat-bedded dune base deposits resemble much those described from modern warm-climate sand sheet deposits (cf. Fryberger et al. 1979, Fryberger et al. 1983, Kocurek \& Nielson 1986), and the deposits are interpreted as a Precambrian sand sheet facies. Most of the sand sheet sediments described here were deposited during dry surface conditions, but at locality A the initial surface was damp as evidenced by the adhesion ripple structures. According to Kocurek \& Nielson (1986) sand sheets are caused by factors that act to inhibit dune development. It is suggested that on the un-vegetated Precambrian surfaces the relatively coarse grain size was the main factor promoting sand sheet development; a high ground water table initially played a role at locality A.

With time the grain size of the sand sheet environment decreased, and small dunes could form locally as seen at locality A.

The coarse grains of the sand sheet deposits may have been introduced into the area by peri- 


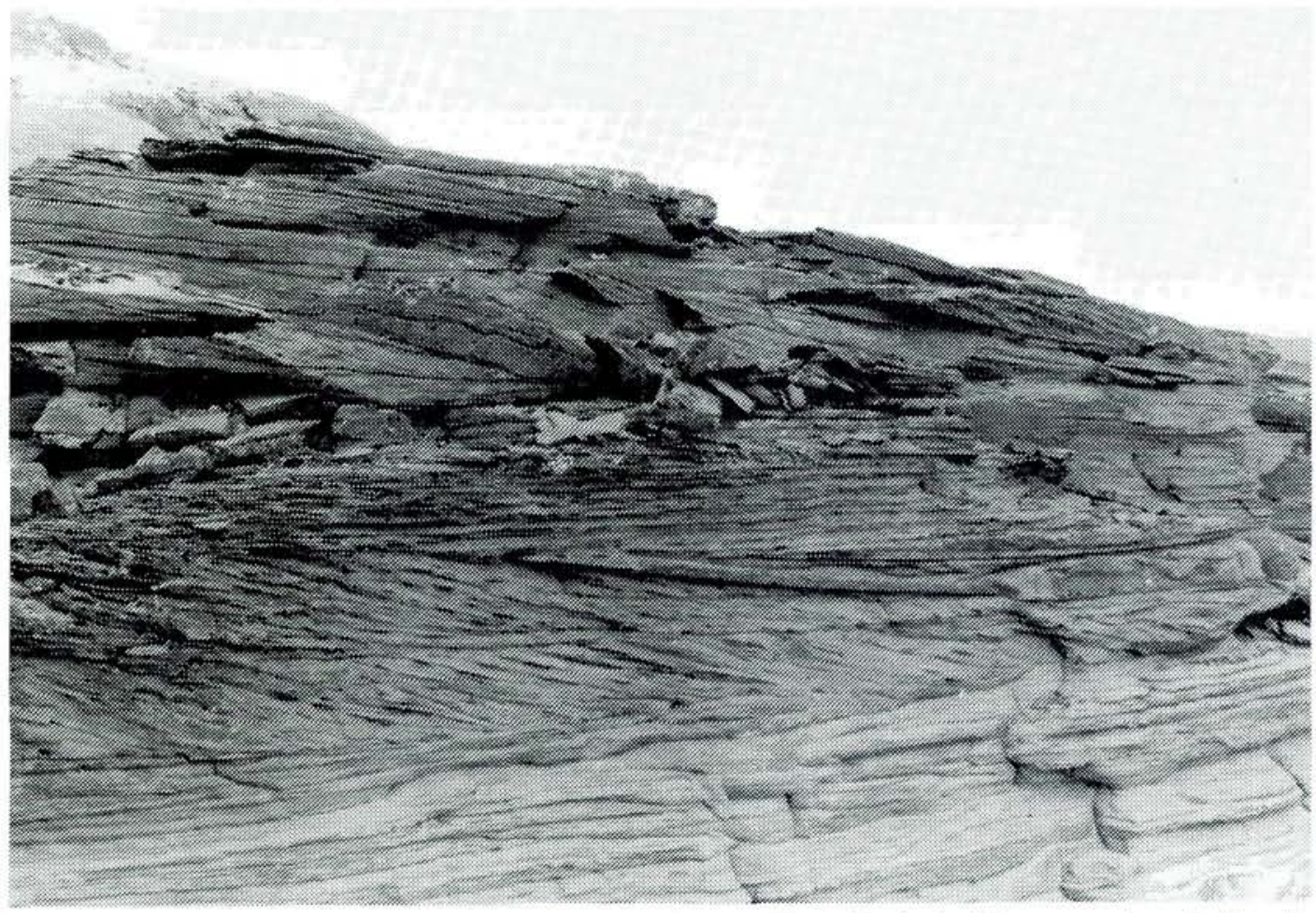

Fig. 4. Compound cross-bedding in dune topsets of dome-shaped dune, locality A. Crossbeds of the compound cross-bedding dip towards northern direction. Thickness of exposure c. $2.5 \mathrm{~m}$.

odic flooding from the adjacent fluvial systems, or may have been derived by local erosion of the underlying fluvial deposits.

Dune lee-side deposits

Description. - These deposits can be classified into three types: very low-angle sweeping toeset deposits of fine- to coarse-grained sandstone, low-medium-angle relatively simple foreset deposits of fine-grained sandstone, and mainly lowangle compound foresets or topset deposits of fine-grained sandstone.

The toeset deposits (fig. 3) are composed of gently dipping concave-up wind-ripple produced strata, which include some coarse sand ripples and 'shields'. The foresets are arranged in $0.4 \mathrm{~m}$ to c. $1.0 \mathrm{~m}$ thick subparallel subsets separated by third order bounding surfaces.

The relatively simple foreset deposits comprise low-medium-angle layers of grainfall and rippleproduced strata; sandflow strata are absent. The foresets dip towards WNW, and the maximum dip of the foresets is between 14 and 24 degrees. The foresets may contain some intrasets and commonly contain third order bounding surfaces that divide the foresets into several subsets with slight variation in strike and dip.

The compound foreset or topset deposits show compound, generally very low-angle (5-15 degrees) cross-bedding (fig. 4). The cross-beds of the compound cross-bedding are medium-scale $(0.1-0.5 \mathrm{~m})$ trough-shaped or semitabular and dip towards the north. Both simple and compound lee-side deposits are frequently convex-up (Fig. 5).

The foreset and topset deposits contain numerous small-scale deformation structures, but no large-scale contorted layers.

Interpretation. - The toeset strata apparently formed as dune apron deposits at the base of the dune lee-face. The wind-ripple produced strata indicate tractional deposition, which could be linked to secondary lee-eddy winds, to surface winds that blew along or up the lee-slope, or to surface winds that blew down the lee-slope of a 


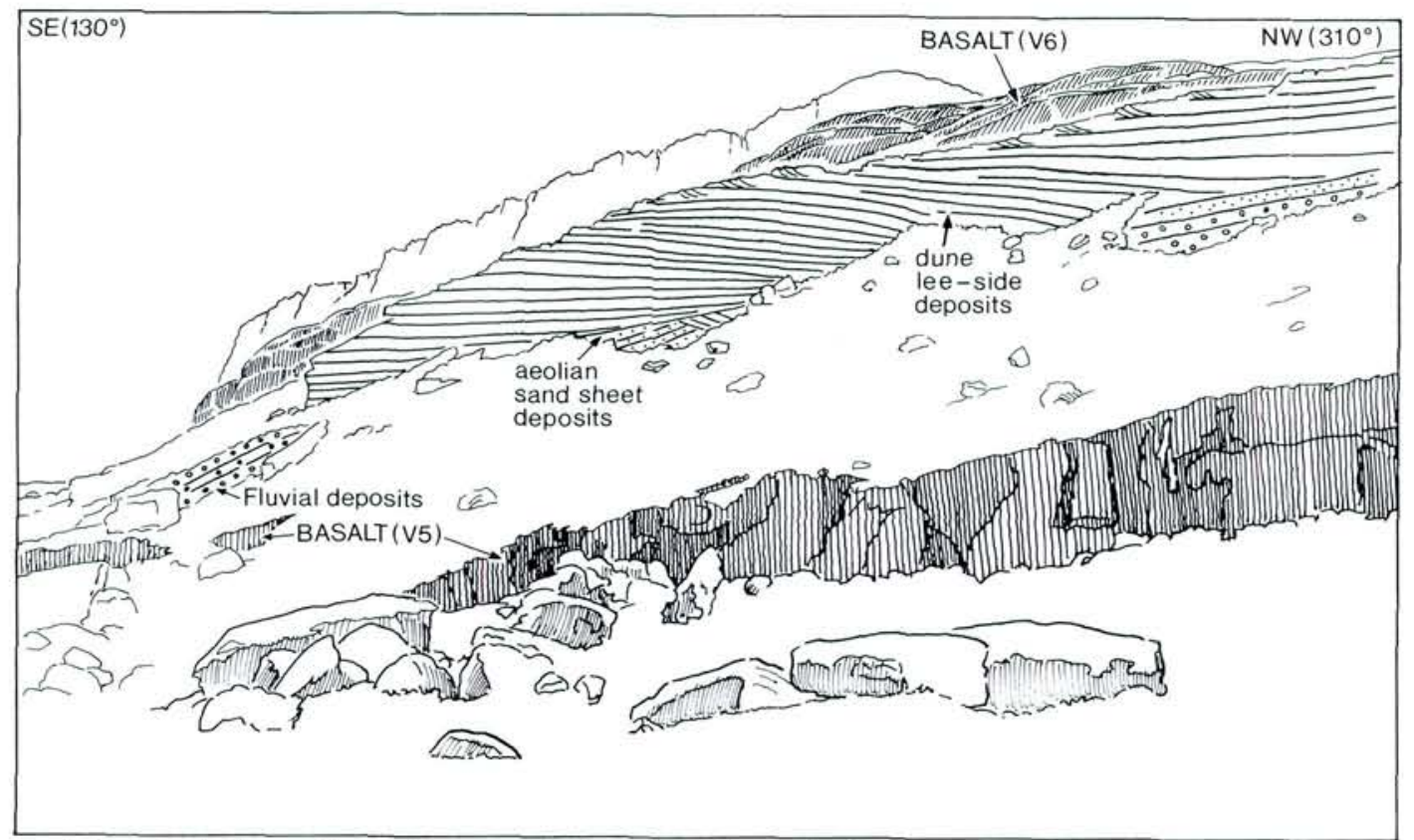

Fig. 5. Geological setting and dune architecture of the dome-shaped dune at locality A. Note the occurrence of convex-up strata in the central part of the aeolian sandstone body. Sketch after photograph. Maximum height of aeolian sand body is $10 \mathrm{~m}$.

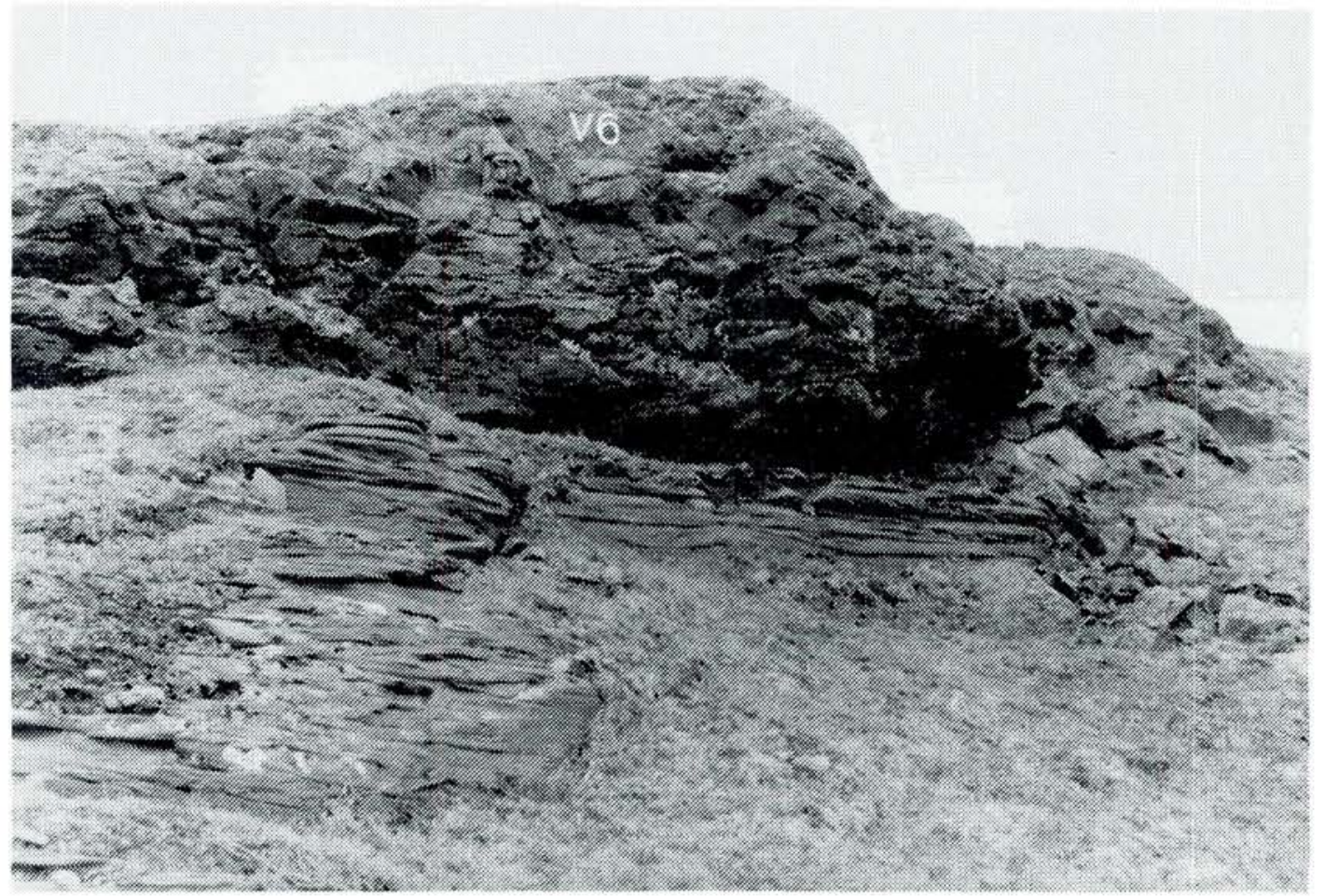

Fig. 6. Contact between dune deposits and overlying lava flow (V6) at locality C. Medium-angle relatively simple foresets at the base of the photograph is gradationally replaced upwards and downwind by compound dune foresets. Dune foresets dip towards the NW. Visible height of lavaflow c. $3 \mathrm{~m}$. 
dune that did not have a zone of flow separation (cf. Hunter 1981).

The relatively simple foreset deposits formed on the downwind-migrating lee-slope of a dune. The relatively low dip is partly due to compaction, but lack of sandflow strata suggests that the lee-face did not contain any active slipface. The common third order reactivation surfaces indicate repeated periods of wind erosion on the dune lee-face.

The compound foreset and topset deposits probably mainly formed at the upper lee-slope of a dune. The compound cross-bedding (cf. Rubin \& Hunter 1983, Rubin 1987) sugests that this part of the dune was covered by smaller aeolian bedforms that migrated along-crest or obliquely down-crest.

\section{Dune architecture and fossil dune type}

Architecture

Dune architecture refers here to the internal organisation of the dune deposits. At locality A the aeolian deposits constitute one major cross-bedded unit (fig. 5). Upwind (i.e. towards the SE) low-medium angle relatively simple concave-up foresets dominate; these are underlain by gently dipping relatively coarse-grained toeset deposits (fig. 5). Downwind these layers are gradually replaced by convex-up cross-strata (fig. 5) in which the upper parts (topsets) are composed of compound cross-beds, while the associated foresets appear more simple. Here toesets are finer grained and not easily differtentiated from the basal foresets. Further downwind the cross-bedded unit is cut by a major sill.

At locality $B$ the sequence is dominated by westwards dipping simple to compound foresets, but the degree of exposure is not sufficient to allow any detailed architectural studies.

At locality $\mathrm{C}$ the deposits once again seem to represent the deposits of a single cross-bedded unit (fig. 6). Upwind the aeolian deposits constitute a c. $10 \mathrm{~m}$ thick unit of relatively simple foresets. Downwind, within a distance of c. $25 \mathrm{~m}$, the preserved thickness of the foreset deposits decrease to c. $3 \mathrm{~m}$, and in this direction mediumscale intrasets increase in importance (fig. 6).
Toeset deposits are relatively fine-grained at this locality and do not differ much from the basal foreset deposits.

\section{Fossil dune type}

The architectural build-up of the dune body at locality A (fig. 5) and in particular the low-angle of dip and convex-up cross-strata show much resemblance to structures revealed in trenches in modern dome-shaped dunes (cf. McKee 1966, Fryberger et al. 1983). Also the dominance of wind-ripple produced strata and the lack of sandflow strata support an interpretation of the ancient cross-strata as fossil dome-shaped dunes. To judge from the features of the cross-strata the dune apparently began as a crescentic dune; the slipface of this dune was not well developed, or at least its deposits are not preserved. With time this dune developed into a dome-shaped form. The preservation of topset deposits indicates that a significant portion of the dune was preserved. This aspect will be discussed later.

The compound cross-bedding in the upper part of the dune body at locality A clearly indicates that smaller aeolian bedforms were superimposed on the upper lee-face of the dune. In his investigation of a dome-shaped dune in the White Sands McKee (1966) described the existence of common aeolian megaripples on the dune stoss side. If similar smaller-scale aeolian bedforms were developed also on the ancient dune leeface, trough-formed cross-bedding would result from the interaction of the main dune and the superimposed bedforms (cf. Rubin 1987). The ancient aeolian bedforms could therefore be classified as complex dome-shaped dunes.

\section{Palaeowind regime}

Measurements of the large-scale simple foresets that constitute the bulk of the dune deposits yield a narrow spread of dip directions towards the NW (fig. 7). This is taken to indicate that dominant sand transport was towards the NW, and that prevailing winds blew from the SE. The cross-beds (scour pits) of the compound crossbedding dip towards northern directions (fig. 7). As the main dune lee-side probably moved slowly forward at the same time as the superimposed 

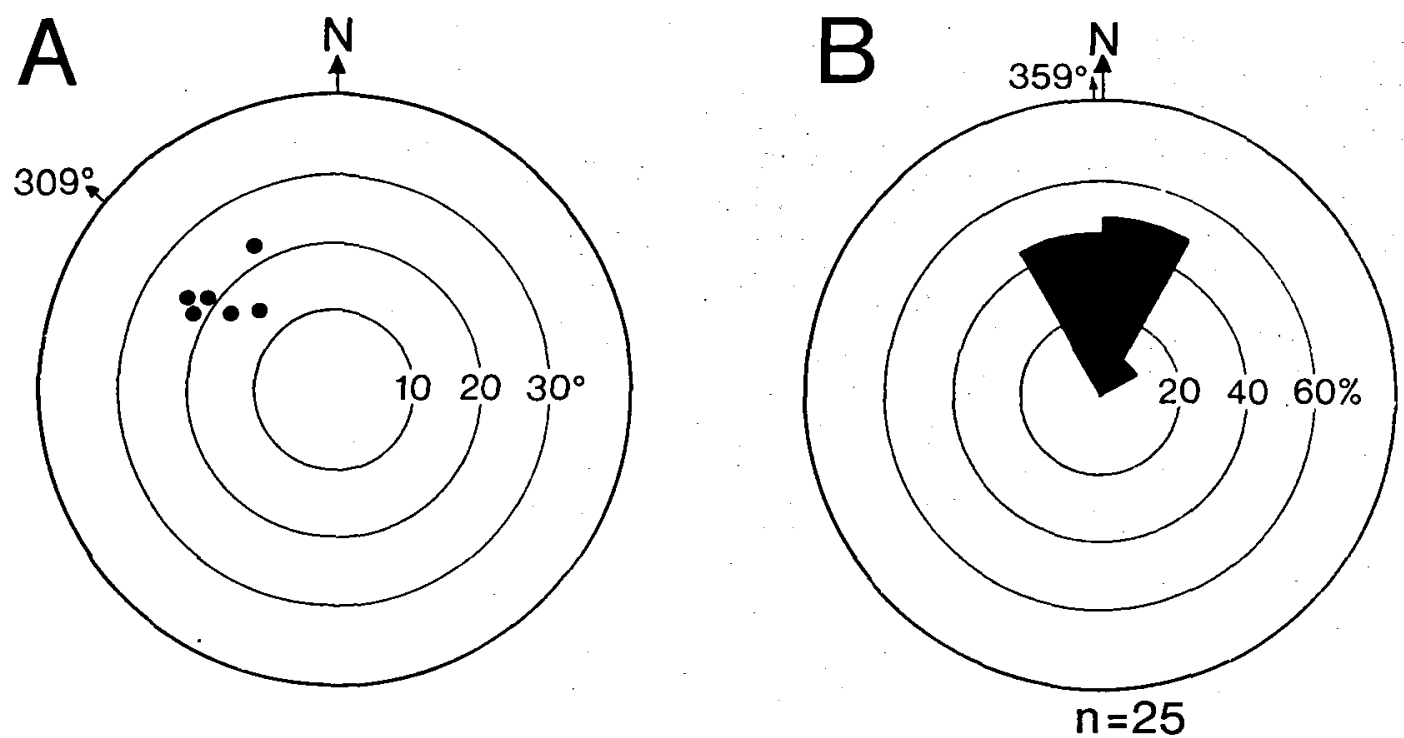

Fig. 7. Cross-bed orientation in the dome-shaped dune deposits. A. Large-scale, simple foresets. B. Cross-beds of the compound cross-bedding.

bedforms migrated along-crest or obliquely down-crest, the scour-pit path orientation would not exactly parallel the migration direction of the superimposed bedforms (cf. Rubin 1987). In the present case, however, the speed ratio (superimposed bedforms to main bedforms) most likely was high (10 or more) meaning that the true migration direction of the superimposed bedforms was only a few degrees more easterly than the scour-pit path. Since the main dunes were dome-shaped it is probably safe to say that there was no significant flow separation airflow on the dune lee-sides, and that the superimposed dunes therefore migrated under the direct influence of seasonal strong, primary winds from the $S$.

Palaeolatitude maps of Irwing (1979) indicate that South Greenland was situated between c. 10 and c. 25 degrees north in the period c. 1325$1400 \mu$, and that Greenland was rotated c. 90 degrees counterclockwise in relation to its present position. Assuming that the age of the Mussartût Member was not much older than $1320 \mu$ (cf. Upton \& Emeleus 1987), it is possible that South Greenland at that time was situated within a Premcambrian trade wind belt. Hence the deduced palaeowinds might represent prevailing trade winds blowing from NE (SE in present-day outcrops) and periodic strong winds blowing from the $E$.

Not much is known on the wind regime of small dome-shaped dunes. According to McKee (1966) dome-shaped dunes develop where dune height is limited by an unobstructed strong wind. Dome-shaped dunes are therefore common in the upwind parts of some dune fields or sand seas (Breed \& Grow 1979). Fryberger et al. (1983, 1984), however, describe dome-shaped dunes also from the central and downwind parts of the Jafurah Sand Sea, Saudi Arabia. They note here the gradual change of dome-shaped dunes to barchans, and vice versa. They suggest that domeshaped dunes can exist as stable bedforms and migrate for considerable distances.

\section{Geometry of the aeolian deposits}

\section{Boundaries}

The aeolian sandstones overlie fluvial conglomerates and pebbly sandstones that form the initial deposits in C5. The contact appears sharp, although good exposures are few. Traced laterally the contact is flat-lying and without significant undulations. The fluvial deposits fine upwards towards the contact with the aeolian deposits; aeolian deflation lags are seemingly absent at the fluvial-aeolian contact.

The contact between the aeolian sandstones and the overlying lava flow is sharp and clearly erosive. Sandstone inclusions and sandy matrix 


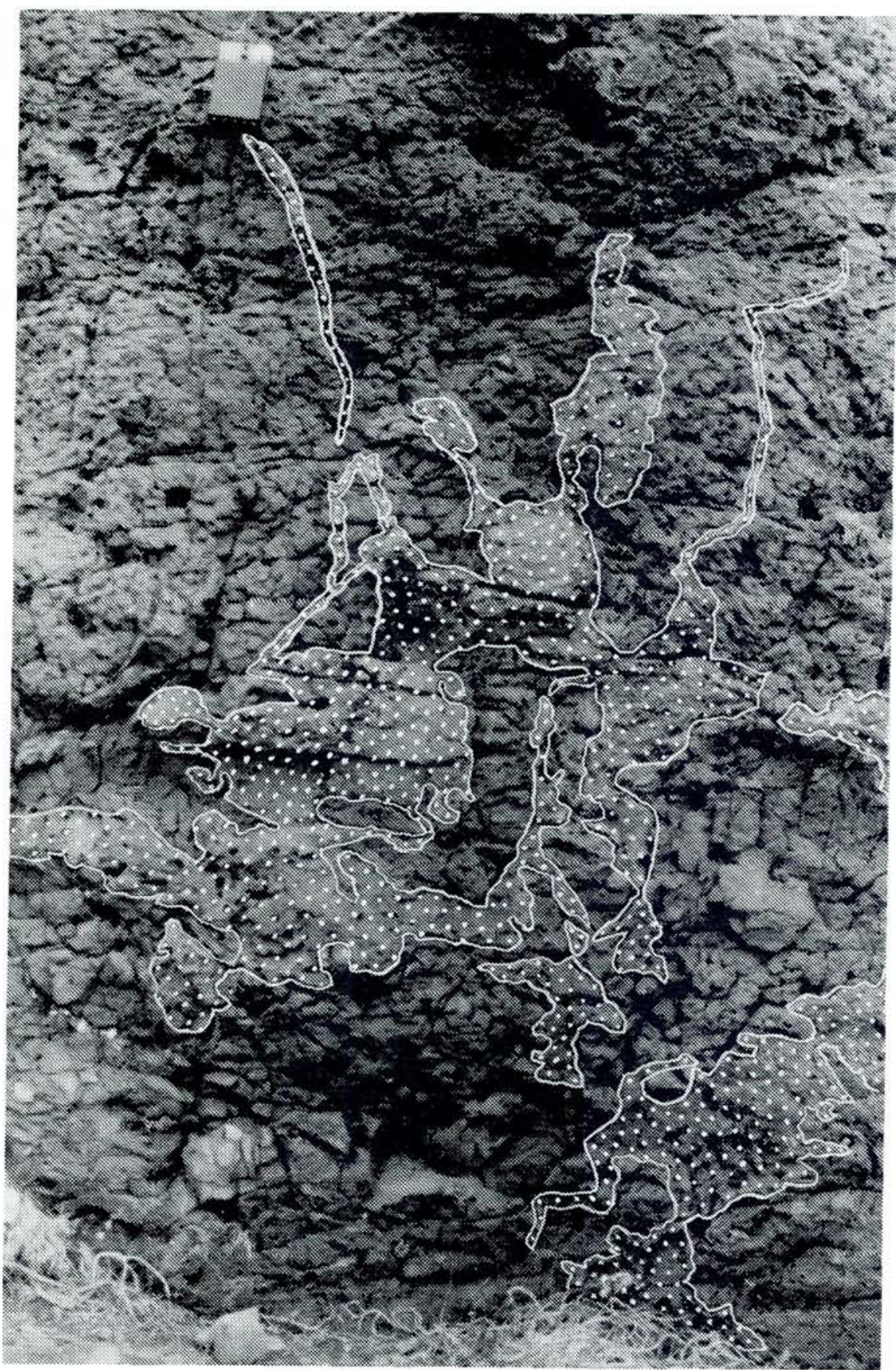

Fig. 8. Basal part of the lava flow (V6) immediately above the contact to the dune deposits. Sandstone inclusions are indicated. Compass for scale.

are common in the lowermost part of the lava flow in association with scoriaceous slabs (fig. 8). The sandstone inclusions are of highly irregular size and shape and commonly display offshoots of thin sandstone dykes (fig. 8). The sandstone inclusions are structureless; their boundaries to the volcanic material are mostly sharp, but can also be gradational. The sandstone content rapidly 

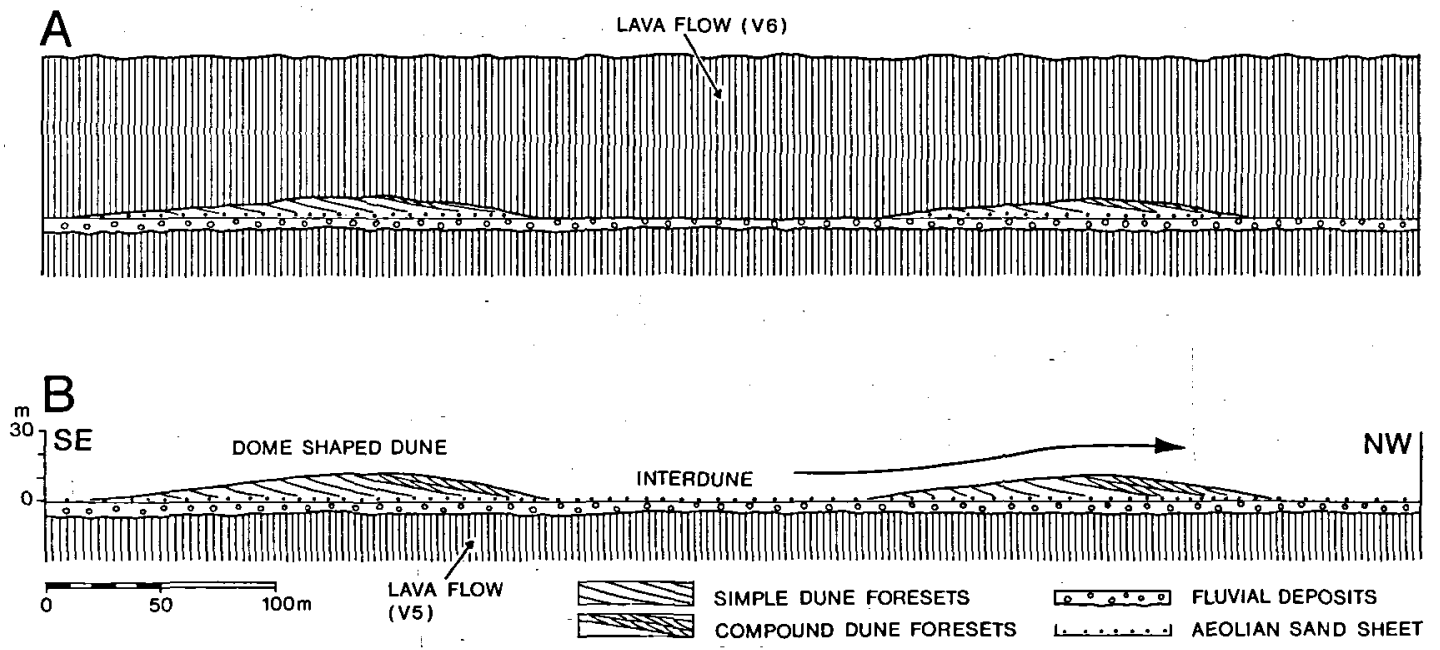

Fig. 9. A. Tentative reconstruction of aeolian landscape prior to the extrusion of the lava flow. The extent of interdune sedimentation is unkonwn. B. Aeolian morphology preserved by lava cover (V6).

decreases upwards from the base of the lava flow and is virtually absent $2 \mathrm{~m}$ above the base. In the uppermost $10-50 \mathrm{~cm}$ of the aeolian sandstones there is evidence of baking by the lava flow.

The sandstone-lava flow contact is clearly undulatory and within the area studied three domeshaped accumulations of aeolian sandstones have been recognized.

\section{Thickness}

The thickness of the aeolian deposits varies be= tween nil and c. $10 \mathrm{~m}$. At three localities (A, B, $C)$ in the area studied there are dome-shaped accumulations of aeolian sandstones. The summits of these sandstone accumulations lie c. 400 $\mathrm{m}$ apart, and are separated by relatively wide areas without any aeolian deposits. The widths of the aeolian sand-free areas between the domeshaped accumulations can only be estimated because of the rather poor degree of exposure, but must be of the order of $150-300 \mathrm{~m}$ as measured parallel with the prevailing palaeowind direction (i.e. from SE to NW).

At locality A, which is by far the best exposed of the three localities, the dome-like accumulation of aeolian deposits has a width of c. $200 \mathrm{~m}$ and a maximum thickness of c. $10 \mathrm{~m}$ of which dune lee-side deposits constitute the uppermost 8 $\mathrm{m}$. The upper surface, which is directly overlain by the lava flow, is very smooth and dips gently away from the top of the dune accumulation. The stoss side dips up to $7^{\circ}$, and the lee-side about the same, but the downwind termination of the dune is masked by an intrusive dyke.

At locality $B$ the exposure is too small to allow any assessment of the dune form.

At locality $\mathrm{C}$ the dome-shaped accumulation of aeolian sandstones is only partly exposed. The accumulation is at least $10 \mathrm{~m}$ thick and dominated by dune lee-side deposits. Its upper surfaces forms a gentle slope dipping up to about $15^{\circ}$ towards the NW. Thus the upper surface is nearly conformable to the internal foreset bedding in the dune (fig. 6).

\section{Significance}

The main question that remains to be answered is whether the dome-like accumulations of aeolian sandstones described in the foregoing reflect the original topography of dome-shaped dunes with intervening flat-lying interdune areas, or whether the surface of the aeolian accumulations is merely an accident of erosion at the base of the lava flow.

There appears to have been relatively little erosion at the base of the lava flow, to judge from the limited thickness of the sandstone-bearing zone at the base of the lava flow. Also where the lava flow directly overlies the fluvial deposits there is only evidence of minor erosion. The lack of significant erosion and of large-scale deformation at the base of the lava flow may be due to the 
fact that the lava flow advanced very slowly (aa type) in a caterpillar-track fashion over a layer of fragmented lava.

The markedly dome-shaped appearance of the dune accumulations, in particular at locality $\mathrm{A}$, is thought therefore to reflect the initial topography of dome-shaped dunes separated by interdune flats.

Modern dome-shaped dunes are frequently relatively small. A typical dome-shaped dune at White Sands, New Mexico is $6 \mathrm{~m}$ high and 140 in length (McKee 1966), and has a form index of 23.3. Dome-shaped dunes near Dharan, Saudi Arabia, are between 5 and $12 \mathrm{~m}$ high and have lengths between 120 and $250 \mathrm{~m}$ (Fryberger et al. 1983).

The dome-shaped dune deposits at locality $\mathrm{A}$ have a preserved maximum height of c. $8 \mathrm{~m}$, a downwind extension of c. $200 \mathrm{~m}$ and a form index of 25 . This suggests that most of the original dune (perhaps as much as $90 \%$ ) was preserved here below the lava flow (fig. 9).

Modern dome-shaped dunes of the Jafurah Sand Sea, Saudi Arabia, occur in isolation or in dune complexes (Fryberger et al. 1984). Although only a limited part of clastic interval 5 has been studied so far, it seems that the ancient dome-shaped dunes here were part of a dune complex with dune spacing around $400 \mathrm{~m}$, and that the dunes were separated by interdune flats with a downwind width of about $200 \mathrm{~m}$ (fig. 9).

\section{Aeolian sequences and dune field dynamics}

The aeolian sequence begins with a thin and patchily preserved sand sheet deposit which rather abruptly overlies fluvial deposits. On top of the sand sheet deposits follows a single unit of dome-shaped dunes. These dunes migrated towards the NW (present day position) and the aeolian system seems to have encroached on the distal areas of an alluvial fan system which received progressively less coarse material from the NW (Pedersen 1988).

According to Porter (1986) ergs (aeolian sand seas) are characterized by a downwind zonation into fore-ergs, central ergs and back-ergs. The fore-erg zone consists of sand sheets, zibars and small duness, while the central erg contains large dunes and draas. In the present case therefore it is possible that the basal sand sheet deposits represent the fore-erg, and the dome-shaped dunes the downwind part of the central erg, and that the erg was migrating towards the NW.

Alternatively the aeolian deposits in C5 may record the development of a local, small dune field that was unrelated to any large-scale erg systems. Support of the former hypothesis is found in the occurrence of relatively thick aeolian deposits in clastic intervals 2 and 3 (Pedersen 1988). Only extended studies of C5 on a more regional scale can solve this problem definitely.

Whatever the geographical extension of the aeolian dunes in C5, continued migration of the dunes was abruptly terminated by the extrusion of a thick lava flow.

\section{Conclusions}

1. The Middle Proterozoic Mussartût Member of the Eriksfjord Formation in South Greenland consists of alternating sedimentary (continental clastic deposits) and volcanic intervals.

2. One of the clastic intervals (C5) contains up to $10 \mathrm{~m}$ thick aeolian deposits. The aeolian deposits sharply overlie fluvial deposits and are overlain by a thick lava flow.

3. The aeolian deposits are initiated by flat-bedded strata of presumed aeolian sand sheet origin, but the bulk of the aeolian sediments consists of low-angle dune lee-side deposits.

4. The internal architecture of the dune deposits, the low angle of dip, the occurrence of convex-up cross-stata and the absence of sandflow stata all suggest that the ancient dunes were dome-shaped. Dome-shaped dunes have only rarely been recognized in the geological record (Thompson 1969). In the present case their preservation may be linked to the capping lava flow, which arrested the dunes at an early stage of development.

5. Measurements of foreset dip directions in the dunes coupled with data on continental drift $(1325-1400 \mu)$ suggest that the prevailing winds might represent trade winds from the $\mathrm{NE}$ interrupted by strong winds from the $\mathrm{E}$.

6. The aeolian deposits form three dome-shaped accumulations of sandstones within the studied area, and it is suggested that most of the 
original dune form was preserved beneath the encroaching lava flow.

7. The aeolian deposits could represent the foreerg and downwind part of the central erg in a migrating erg system. Continued migration of the aeolian dunes was abruptly terminate by the extrusion of a thick lava flow.

Acknowledgements. - I thank C. Pulvertaft and S. Watt for critical reading of the manuscript. Pernille Andersen typed the manuscript and René Madsen made the drawings. The field work was partly supported by grants from the Danish Ministry of Energy.

\section{Dansk sammendrag}

I forbindelse med en sedimentologisk undersøgelse af den Prakambriske Mussartût Member (Eriksfjord Formationen) i Sydgrønland blev der observeret flere niveauer med roliske sandsten. I klastisk interval fem ligger de æoliske sandsten ovenpå fluviale sandsten og konglomerater, og de æoliske sandsten overlejres direkte af en c. $70 \mathrm{~m}$ tyk Prækambrisk lavastrøm. De xoliske sandsten danner op til $10 \mathrm{~m}$ tykke og $200 \mathrm{~m}$ brede svagt kuppelformede sedimentlegemer, der indledes af tynde og kun lokalt bevarede roliske sandtæppe (sand sheet) aflejringer. Hovedparten af de roliske sandstenslegemer udgøres af relativt lavvinklede leside-aflejringer fra skjoldklitter (dome-shaped dunes). Skjoldklitterne vandrede hen imod et område med alluviale aflejringskegler muligvis under indflydelse af fremherskende nordøstlige passatvinde. Overlejrende mindre klitformer dannedes under periodevis stærke vinde fra øst. Toppen af skjoldklitterne blev kun eroderet lidt under den fremrykkende lavastrøm og hovedparten af skjoldklitternes oprindelige morfologi synes at være blevet bevaret. Skjoldklitterne er muligvis del af et vandrende æolisk sandhav, men yderligere vandring af klitterne blev brat afsluttet ved lavastrømmens ankomst.

\section{References}

Breed, C. S. and Grow, T. 1979: Morphology and distribution of dunes in sand seas observed by remote sensing. in: McKee, E. D. (ed.) A Study of Global Sand Seas. Prof. Pap. U.S. geol. Surv. 1052, p. 253-302.

Emeleus, C. H. \& Upton, B. G. J. 1976: The Gardar period in southern Greenland. in: Escher, A. \& Watt, W. S. (eds) Geology of Greenland, p. 152-181. Copenhagen: Grønlands geol. Unders.

Fryberger, S. G., Ahlbrandt, T. S. \& Andrews, S. 1979: Origin, sedimentary features, and significance of low-angle colian "sand sheet" deposits, Great Sand Dunes National
Monument and Vicinity, Colorado. J. Sedim. Petrol. 39, p. 733-746.

Fryberger, S. G., Al-Sari, A. M. \& Clisham, T. J. 1983: Eolian dune, interdune, sand sheet, and siliciclastic sabkha sediments of an offshore prograding sand sa, Dharan area, Saudi Arabia. Bull. Am. Ass. Petrol. Geol. 83, p. 280-312.

Fryberger, S. G., Al-Sari, A. M., Clisham, T. J., Rizvi, S. A. R. \& Al-Hinai, K. G. 1984: Wind sedimentation in the Jafurah Sand Sea, Saudia Arabia. Sedimentology 31, p. 413-431.

Hunter, R. E. 1977: Basic types of stratification in small eolian dunes. Sedimentology 24, p. 361-387.

Hunter, R. E. 1981: Stratification styles in eolian sandstones: Some Pennsylvanian to Jurassic examples from the western interior USA. In: Ethridge, F. G. \& Flores, R. M. $(e d s)$ Recent and Ancient Non-marine Depositional Environments Models for Exploration. Soc. Econ. Paleont. Miner. Spec. Publ. 31, p. 315-329.

Irving, E. 1979: Paleopoles and paleolatitudes of North America and speculations about displaced terrains. Can. J. Earth Sci. 16 , p. $669-674$.

Kocurek, G. \& Nielson, J. 1986: Conditions favourable for the formation of warm-climate aeolian sand sheets. Sedimentology 33, p. 795-816.

McKee, E. D. 1966: Structures of dunes at White Sands National Monument, New Mexico (and a comparison with structures of dunes from other selected areas). Sedimentology 7, $69 \mathrm{pp}$.

Pedersen, H. L. 1988: Continental rift sedimentation and volcanism, Mussartût Member, Eriksfjord Formation (Precambrian), South Greenland. Unpublished Thesis. Copenhagen University, ?? pp.

Porter, M. L. 1986: Sedimentary record of erg migration. Geology 34, p. 497-500.

Porter, M. L. 1987: Sedimentology of an ancient erg margin: The Lower Jurassic Aztec Sandstone, southern Nevada and southern California. Sedimentology 34, p. 661-680.

Poulsen, V. 1964: The sandstones of the Precambrian Eriksfjord Formation in South Greenland. Rapp. Grpnlands geol. Unders. 2, $16 \mathrm{pp}$.

Rubin, D. M. 1987: Cross-bedding, bedforms and paleocurrents. Soc. Econ. Paleont. Miner. Concepts in Sedimentology and Paleontology 1, $187 \mathrm{pp}$.

Rubin, D. M. \& Hunter, R. E. 1983: Reconstructing bedform assemblages from compound cross-bedding. In: Brookfield, M. E. \& Ahlbrandt, T. S. (eds) Eolian Sediments and processes. Developments in Sedimentology, 38, p. 407427.

Stewart, J. W. 1964: The earlier Gardar igneous rocks of the Ilimaussaq UK, $423 \mathrm{pp}$.

Thompson, D. B. 1969: Dome-shaped aeolian dunes in the Frodsham Member of the so-called "Keuper" Sandstone Formation (Scythian-?Anisian) at Frodsham, Cheshire (England). Sed. Geol. 3, p. 263-289.

Upton, B. G. J. \& Emeleus, C. H. 1987: Mid-Proterozoic alkaline magmatism in Southern Greenland: the Gardar Province. In: Fitton, J. G. \& Upton, B. G. J. (eds) Alkaline igneous rocks. Geol. Soc. Spec. Publ. 30, p. 449-471. 